\section{3. 二重反転プロペラ*}

坂 本 芳太郎** 串山弘*** 新田啓一****

1.はじめに

二重反転プロペラ（以下 CRP）装置は一つの軸 心上に前後 2 枚のプロペラを配置し，互いに反転さ せ，前プロペラの回転流にともなう未活用のエネ ルギーを後ろ側のプロペラで回収して有効な推進 力に変換する省エネ装置である。CRPの利点や原 理は古くから知ら机ていたが，いくつかの技術上 の未解決課題が有った為, 大型CRP装置は近年ま で実現しなかった。

CRPの最適設計法, コンパクトな反転茵車装置， 二重反転軸受, 二重反転シール等の開発が大型商 船用 CRP装置実現の為の技術的課題であるが， 1988年になって, 石川島播磨重工業(株)（以下 I 社）が大型CRP装置の陸上実機公開運転を, 又, 三菱重工業 (株) (以下 $M$ 社) が実船への搭載実現 と相次いで開発の成功を公表した。その後, 1996 年には川崎重工業(株)，住友重機械工業(株)，日 本鋼管(株)，日立造船(株) および三井造船(株) からなる国内5社（以下5社）の共同開発完了とI 社による旋回式CRP装置の開発完了が発表された。

上記は何れも国内の造船会社の手によるもので はあるが，それぞれ個別のコンセプトで開発され ている.

現在は，I社のCRPを搭載した 37,000 トンの貨物 船と 258,000 トンの油槽船打よびM社の装置を搭載 した自動車運搬船と 258,000 トンの油槽船の計 4 隻 のCRP搭載船が就航中である。図1は油槽船に搭 載したI社のCRPの外観である。大型商船にCRP装 置を搭載する主目的は省エネルギーであり，同一 船速で比較すると，1枚プロペラ船に比べて最大 $15 \%$ の馬力削減が可能であるが, 更に, 船体停止 迄の航走距離の短縮や左右の旋回軌跡の対称性の 改善あるいは直進時に当て舵が不要となる等の操

\footnotetext{
*原稿受付 平成 10 年 5 月 29 日

第60回春季学術講演会 (平成10年5月14日)

**正会員 石川島播磨重 L業株式会社（江東区豊洲3-2-16）

$* * *$ 正会員 三菱重工業株式会社（長崎市飽／浦町 1-14)

$* * * *$ 正会員 住友重機械工業株式会社（横須賀市夏島町 19）
}

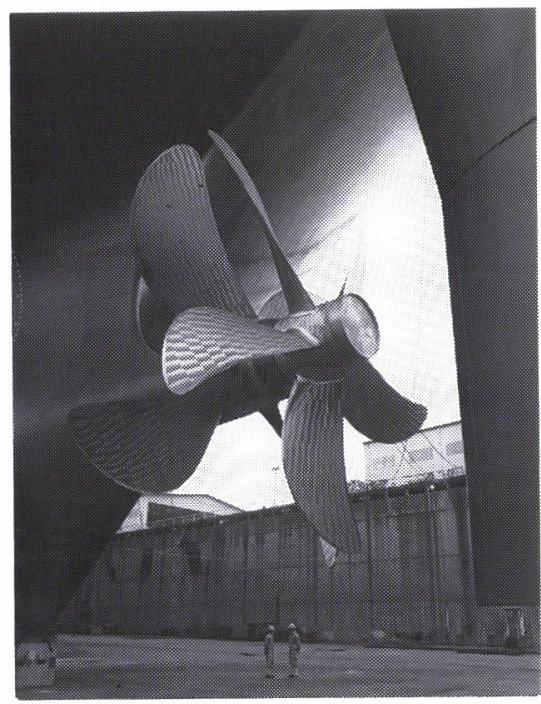

図1 I 社のCRPの外観

縦性能の向上および船体振動一特に後進時の船体 振動一の大幅な減少と言う特長が報告されている. 本報では, 各社の装置の構造に焦点を合わせてそ の特長を説明し，又，実船に搭載運航されている ものについてはその実績を紹介する.

\section{2. 構造と特長}

\section{1 大型商船用 CRP装置}

\subsubsection{I 社の装置軸系装置は四 2 に示す如} く，後プロペラを取り付けた内側プロペラ軸が外 側プロペラ軸を貫通後,中間軸を介して主機に結合 されている。前プロペラは外側プロペラ軸に装着 され，同軸は反転柬車装置に接続している，主機は 中間軸を経由して後プロペラを直結駆動すると同 時に，高弾性継手と反転茵車装置を介して前プロ ペラを逆向きに回転させている。馬力は両プロペ ラに等配分されている。前プロペラのスラストは 同プロペラのボス内に装備されたスラスト軸受を 経由して内側プロペラ軸に伝達され，後プロペラの スラストと共に主機のスラスト軸受に伝えられる.

次に, 主要部品の形式と特長を示す。

a) 二重反転ラジアル軸受：複列自動調心ころ 軸受

(1) 低回転でも負荷能力が低下しない.

(2) 損傷発生から航行不能に至るまでの時間が 長い. 


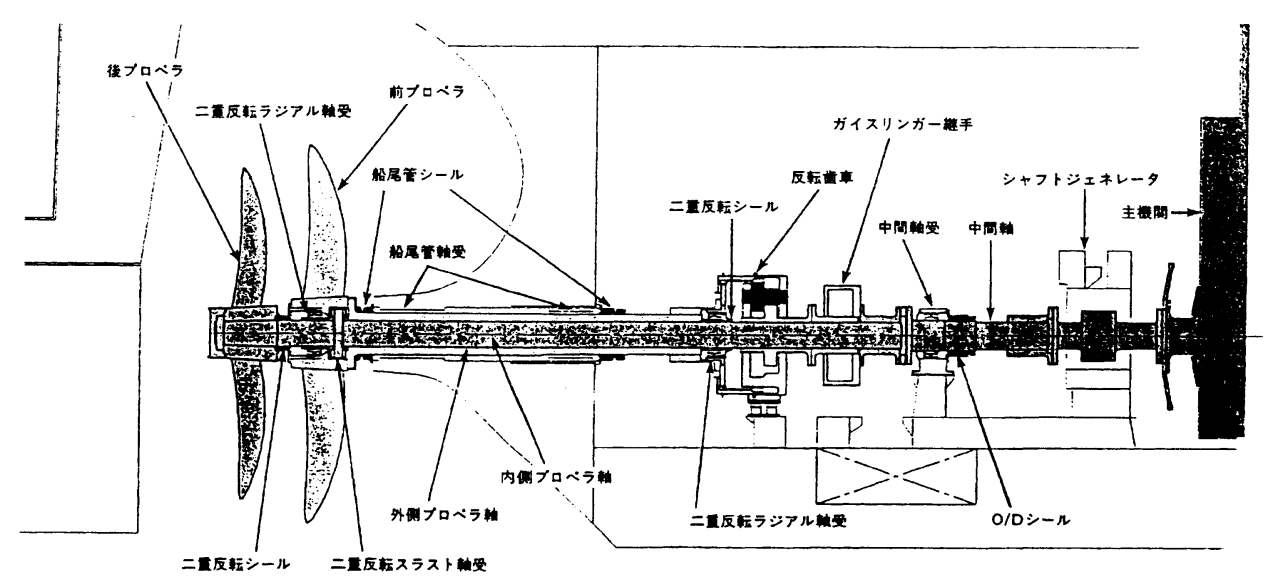

図2Ｉ社のCRP軸系装置

(3) 大型船舶では軸回転数が小さいので，船体 寿命に対して十分に長寿命の設計が可能.

b）二重反転スラスト軸受：前プロペラ内蔵の ティルティングパッド式スラスト軸受

(1) 相対周速が倍増するので負荷能力が増加する.

(2) 機関室内に追加のスラスト軸受けを設ける 必要が無いので, 機器配置上有利。

c) 反転茵車装置：シャフトマゥント式スター コンパウンド型遊星柬車装置（図3）

(1) 前プロペラと後ろプロペラの回転数差を 1 割 とした上で小型化を図れる。

(2) 柬当たりが船体変形の影響を受けない.

d) 二重反転シール装置：予備付リップ式シー ル装置／エヤー吹出し型シール装置

(1) 37,000 トンの貨物船に装備した予備付リッ プ式シール装置は常用シールリングの損傷 に対処可能.

(2) 258,000 トンの油槽船では, 深喫水と装置の

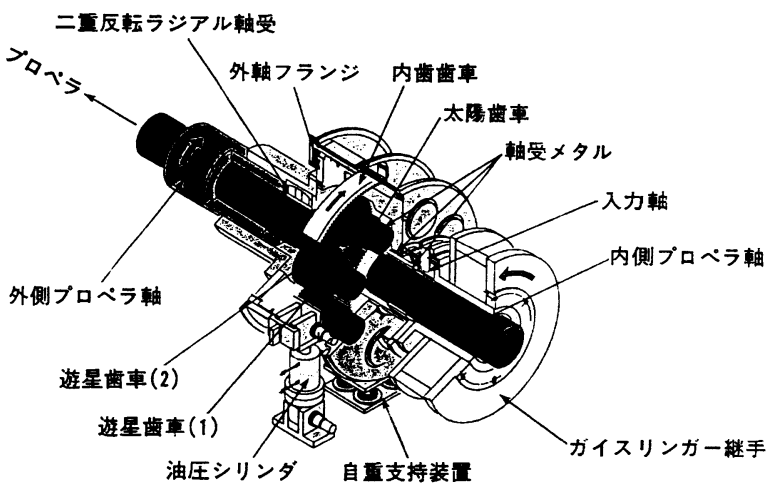

図3 I 社の反転歯車装置
大型化に対応して, エヤー吹出し型シール 装置を採用した。この装置には，軸受潤滑 油と海水を隔てる空気室が設けられており, 万一シールリングを越えて油や海水が空気 室に浸入しても空気流によって船内に回収 されるので, 海洋污染や潤滑油污損の心配 が無い. 又,予備シールリングを内蔵してい るので常用シールリング損傷時に対応可能.

e） その他の特長

(1) 潤滑油システムは反転茵車潤滑システム, 船尾管軸受潤滑システムおよび二重反転軸 受潤滑システムに分けた独立システムとし ているので万一どれかのシステムで海水浸 入等による污損が生じても他へ波及しない.

(2) 前プロペラ駆動系に損傷を生じた場合にも 後プロペラのみで非常航走を続けられるよ うに，万一に備えた同駆動系の分離手段を 2 種類有している。一つは反転茵車の内雬茵 車を船首方向に移動する方法で，もう一つ は高弾性継手への入力部分を切り離す方法 である.

\subsubsection{M社の装置図4にM社のCRP軸系} 装置を示す。キーレスタイプの後プロペラは，反 転茵車及び弾性継手の中心を貫通した内軸に結合 され，主機関に直結している。一方，前プロペラ は外軸のフランジで結合され，この外軸は反転茵 車の出力軸に接続される。後プロペラのスラスト は主機関のスラスト軸受で受け, 前プロペラのス ラストは反転茵車内のスラスト軸受で受けている. 次に, 主要部品の形式と特長について示す. 


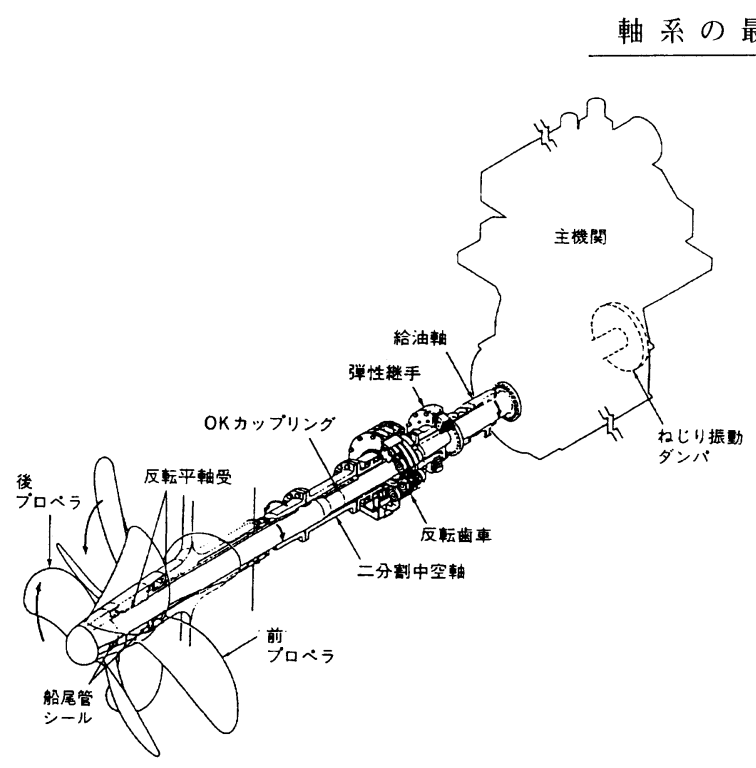

図4 M社のCRP軸系装置

a) 二重反転ラジアル軸受：静圧潤滑式ホワイ トメタル平軸受（図5）

(1) 基本的に従来多用されている滑り軸受なの で信頼性が高く保守も容易である.

(2) 高圧の潤滑油を軸受面に強制的に供給する ので充分な軸受油膜厚さが確保され，かつ， 低速限界がない.

(3) 万一油圧源が裚失しても異速反転による動 圧潤滑作用により軸受油膜を形成出来る.

b) 反転茵車装置: 船体固定式単段スタ一型遊 星茵車装置

(1) 他形式に比ベコンパクトであり, CRP装置 全体のコンパクト化に大きく寄与する.

c) 二重反転シール装置：リップ式シール装置

(1) 軸のラジアル振動への追随性が良好で高周 速に耐えられ信頼性が高い.

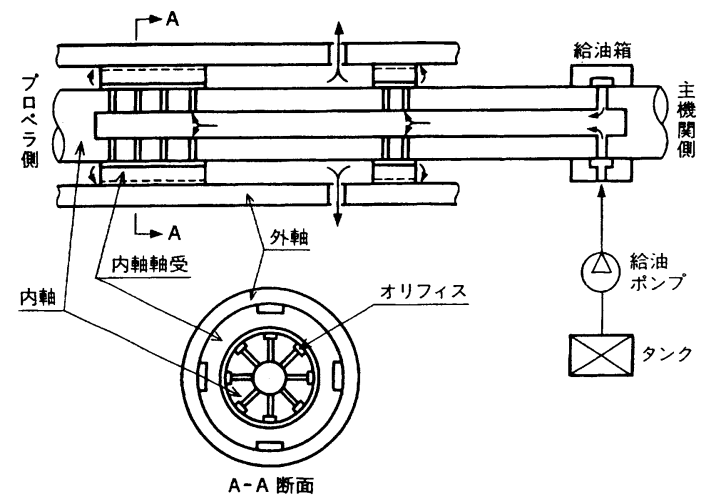

図5 M社の静圧潤滑式軸受
(2) 258,000 トン油槽船では，軸挙動に対して従 来の 2 倍以上の追随性能を有する新形状リ ップシールを採用して，更に信頼性を向上 させている。

d）その他の特長

(1) プロペラ最適設計の面で翼数の異なる 2 個 のプロペラの起振周波数を等しくして, 船 体の防振効果を図る事が出来る.

(2) 前プロペラ系 (外軸系) に万一損傷が起こ った場合でも船内側からの操作により外軸 系を船体に固縛して後プロペラ系（内軸系） のみでの航走が可能.

(3) 万一シール装置にトラブルがあり海水が船 尾管内に浸入した場合でも，従来船と同様 の対応で可.

2.1.35社の装置 四6に280型VLCC軸系 装置の設計例を示す。軸系装置の構成は, 主機出 力軸後部に給油箱と給油軸が配置され, 給油軸後 部で外軸系と内軸系に動力を分けて，外軸系は船 首側から弾性継手, 反転柬車装置, 二つ割中空軸, 圧油導入筒を含む外側プロペラ軸の順に, 内軸系 は内側中間軸, 内側プロペラ軸の順に配置されて いる。内側プロペラ軸は, 外側プロペラ軸の内側 に設けられた船尾側および船首側の反転軸受，す なわちAHT軸受で支持されており，外側プロペラ 軸に対して反転する.

次に, 主要部品の形式と特長を示す.

a) 二重反転ラジアル軸受：AHT軸受

AHT軸受は高圧の潤滑油で軸を支える静圧軸受 であるが, 軸受面にテーパランド形状を複数個設 けた，いわゆるテーパランド軸受を採用したもの で，静圧型と動圧型両者の長所を持った特殊滑り 軸受である（図7）。

(1) 給油孔を内軸の中心部から外周面に放射状 に一列設け，その給油孔出口に軸方向に長 い長方形の給油溝を設けているので，少な い給油量で必要な静圧性能が可能である.

(2) 軸受面にテーパランドを採用したことによ り, 内外軸の反転比の広い範囲で動圧性能 を確保できるので，万一の電源喪失時など でも軸受油膜の保持が可能となる。

b) 圧油導入筒：内軸と外軸の環状隙間に圧油 導入筒を装備する方式

(1) 船尾側と船首側の反転軸受からの潤滑油の 


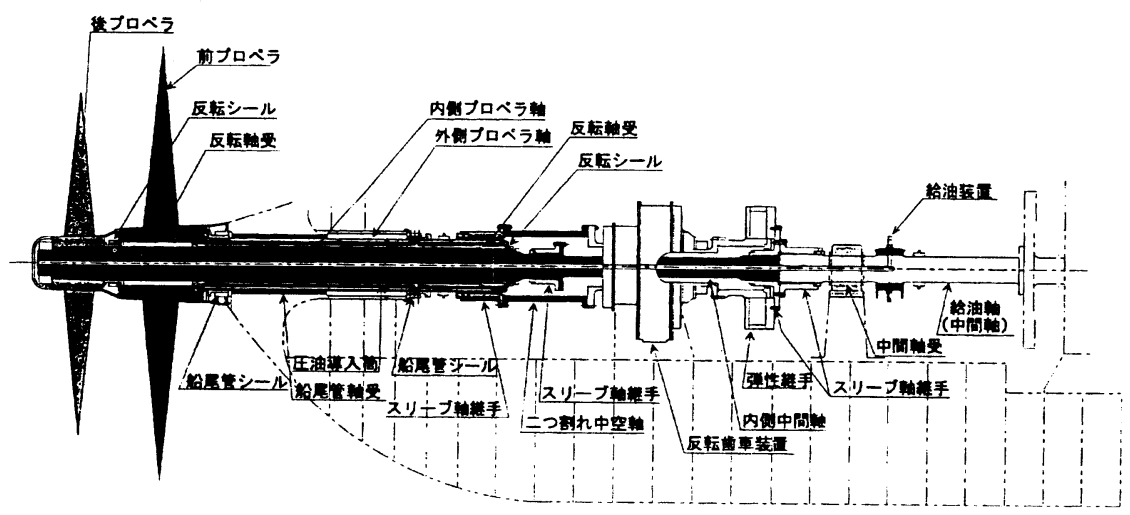

図6 5社のCRP軸系装置

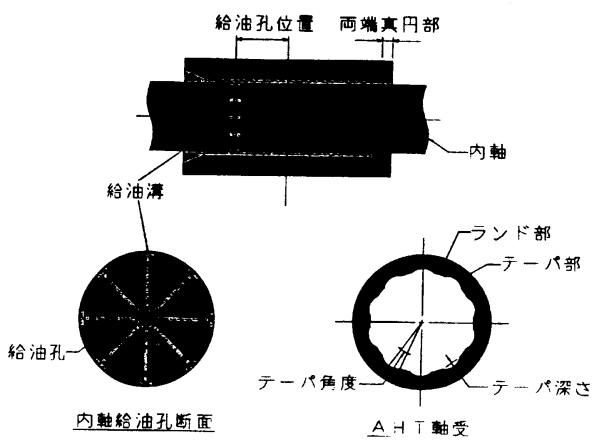

図75社のAHT軸受

排出および反転シール用潤滑油の供給・排 出を確実かつ効率的に行うことができる.

(2) 外側プロペラ軸へ挿入する前に圧油導入筒 外周面で潤滑油の供給・排出用の配管装置 や, 反転軸受温度監視用センサーのリード 線などの計装品の取付作業が飛躍的に容易 かつ確実に施工可能となる.

c) 反転シール：リップ型シール装置

(1) 従来船での豊富な実績があり，信頼性が高い.

(2) 外軸船首側シール装置を通して内側反転シ 一ル装置への供給を可能としている.

d) 反転茵車装置：浸炭処理材等の使用により 小型軽量化を図った遊星茵車方式

(1) スラスト軸受を内蔵し, 前プロペラのスラ ストを分担させたことにより主機と遊星茵 車間への弾性継手の装備を可能とした.

(2) 遊動輪の採用による偏荷重の防止を図って いる.

2.2 I 社の旋回式CRP装置 旋回式CRP
装置の外観を図8に，構造を図9に示す，後プロペ ラを装着した内側プロペラ軸は外側プロペラ軸を 貫通後, 前側の金柬車へ結合し, 前プロペラを装 着した外側プロペラ軸は後側の金茵車へ結合して いる．両金茵車はこれらと直角をなす 1 枚の駆動金 柬車に接続され等速反転し，馬力も等配分されて いる. 同駆動傘茵車は垂直方向の中間軸を介して, 上部の茵車機構に接続され, 水平方向に向きを変 えて主機へとつながっている。両プロペラのスラ ストは各プロペラ軸から円錐ころ軸受を経由して 船体構造に伝達される。

主要部品の形式と特長は次の通りである.

a) 二重反転ラジアル軸受：ころ軸受

(1) 2.1.1で述べた特長を持つ.

(2) 1 枚プロペラ旋回式推進装置での多数の採用 実績により高い信頼性が確認されている.

b) 反転蒾車装置 : 対向配置スパイラル金茵車

(1) 1 枚プロペラ旋回式推進装置での多数の採用 実績により高い信頼性が確認されている.

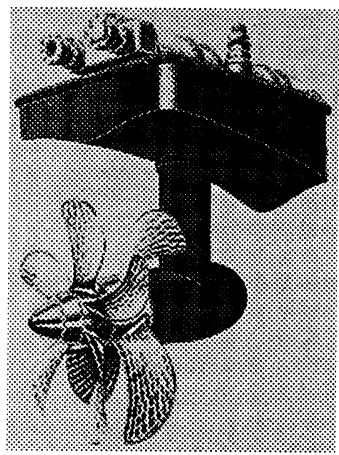

図8Ｉ 社の旋回式CRP装置の外観 


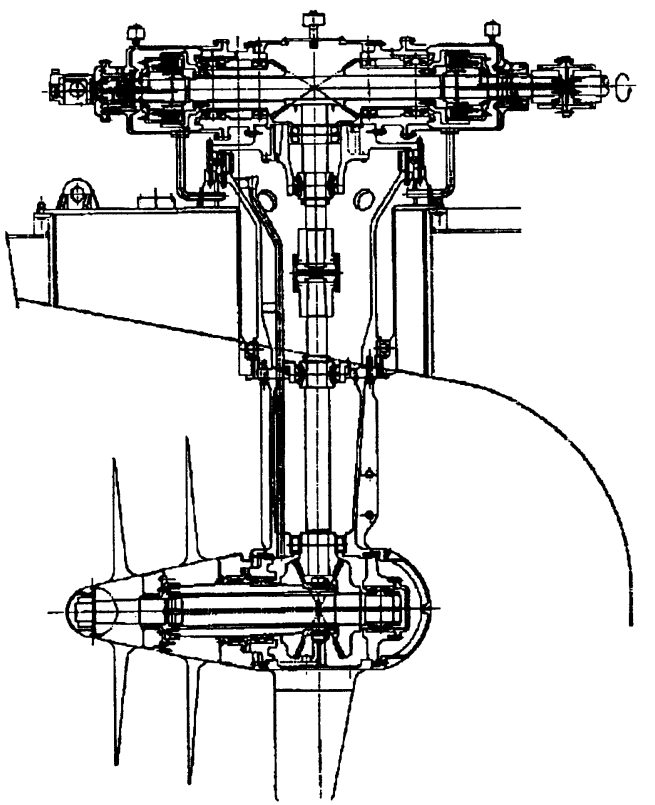

图9Ｉ社の旋回式CRP軸系装置

(2) 反転機構をコンパクトに出来る.

c) その他の特長本装置は主として内航船 舶の近代化と課題解決に寄与させるべく開発した もので, 次の利点を有する.

(1) プロペラ推力が直接舵力として働くことに より旋回性能が向上する. 又, スラスターとして の効果を備えている.

(2) プロペラ・推進軸・減速機構のパッケージ 化により, 船内艤装工事の簡略化, 保守・整備の 容易化, 機関室スペースの縮小と有効利用が可能 となる。

\section{3. 実}

\section{綪}

3.1 I 社の装置Ｉ社では, 1989年に37,000 トンの貨物船に，その後，1993年には25,800トン の油槽船にCRP装置を搭載して, 海上試運転およ び就航後の実績から，14〜15\%の省エネ効果, 操 縦性能の向上, 船体振動の低減を確認している. 1998 年 1 月に貨物船の 2 度目の軸抜き開放検査が実 施され，9年間の使用後も全く問題の無い事が確認 されており，同 2 月には，油槽船が 5 年目のドック をしたが，問題の無い事を確認の上，船級協会の 承認を得て軸抜き検査を省略している.

$3.2 \mathrm{M}$ 社の装置 $\mathrm{M}$ 社では, 1988年に自動 車運搬船に，1993年には258,000 トン油槽船にCRP 装置を搭載して引き渡した。海上試運転や就航実

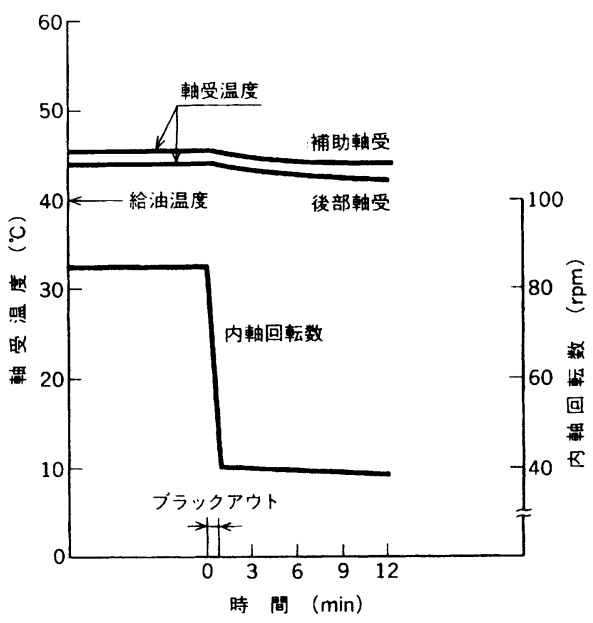

図10 M社の静圧潤滑式軸受の油膜形成

績からは, 約 $15 \%$ の省エネ効果, 操縦性能の向 上, 船体振動の低減等が確認された.

本 CRP装置の要となる二重反転軸受性能につい ては，海上試運転時に油膜厚さ計測を実施した結 果, 低速回転時でも充分油膜厚さが確保されてい ることを確認した。また，ブラックアウト等によ る油圧源喪失時に於いても異速反転効果による油 膜形成があり全く問題のないことを確認した（図 10 参照).

自動車運搬船では，1997年に2回目の軸抜き開 放による定検を，258,000 トン油槽船では1998年に 5 年目の定検（軸は無開放）を実施し，いずれも問 題のないことを確認した.

\section{4. ま め}

日本国内に打いて，3種類の大型商船用CRP装 置が世界に先駆けて開発され，4隻のCRP搭載船 が成功裏に運航されていることは国内造船所の高 い技術開発力を示すものである.

これらの実用化されたCRP装置は海上試運転の 成績や運航実績から大きな省エネ効果と高い信頼 性を示しているが，開発着手当時の予測を外れて 燃料価格が下落したことや船価の低迷も手伝って 残念ながら大型CRP装置の普及は進んでいない.

しかし，近年，地球環境の保護の観点から省工 ネが強く求められる様になったのを機に，やがて CRPがその一翼を担える時代が来るのではないか と, 開発当事者として期待するところは大きい. 